\title{
Productivity Improvement Of Corrugated Carton Industry By Implementation Of Continuous Improvement, 5s, Work Study, And Muda Elimination: A Case Study Of Xyz Co., Ltd.
}

\author{
Piyachat Burawat
}

\begin{abstract}
The purpose of this study is to make productivity better by means of $5 S$, work study, and Muda elimination in corrugated carton industry which was conducted from November 2018 to March 2019 from a case study of XYZ Co., Ltd. The data were collected from managers and supervisors and the problems were analyzed by brainstorming together with cause and effect diagram. Crucial problems of production occurred from human errors, i.e. production employees ignored to check the availability of machines before operating the machine, production employees neglected to prepare materials for next orders while machines operating, and warehouse employees randomly checked the humidity before the storage of corrugated sheet papers. Employees could be trained about production process, machine operation, quality inspection, and planning process. The production process could be changed from operating machine without checking machine availability and removing material remains in the machine to check availability and removing materials remains in the machine before operating new purchasing order. The output was then increased from 2,000 to 2,300 ton per month, accounting for 15.00 percent of improvement. The defect was reduced from 160 to 140 pieces per month, accounting for 12.50 percent of improvement. Regarding the storage process, it could be changed from random check of humidity to check of humidity every time. The messy in warehouse had caused mixing of wet or damp raw materials with good quality raw materials. Once it was improved by cleaning, classifying materials, products and areas with sign boards, the results showed that the materials and products were easier to find and product quality was increased. Company launches $5 S$ policy and doing $5 S$ activities continuously twice a month. The findings presented that the number of employees who neglected to comply with the organizational regulations was reduced from 6 to 2 persons, accounting for 66.67 percent of improvement.
\end{abstract}

Keywords: Muda elimination, Productivity, 5S, Work study

\section{INTRODUCTION}

Recently, productivity improvement is one of the most important to business operation and management, which can be applied in both manufacturing and service industry. Due to ferocious competition in all businesses, particularly in corrugated carton industry, which is competitive in aspects of price, product quality, time delivery, and customer satisfaction, cross-border business, electronic commerce business, opening countries and trade zones in both the

Revised Manuscript Received on April 19, 2019.

Piyachat Burawat, Faculty of Business Administration, Rajamangala University of Technology Thanyaburi / Pathumthani, Thailand.
Eastern and Western countries, has become a stimulus for business needs to be adapted to keep up with the changing business circumstances. This new knowledge-based challenge requires effective management tools to assist the company to meet customer requirements. During the past periods, the principles and theories of modern production and quality improvement have always been developed.

According to high competition and rapid changing business conditions as well as quality and waste problem in both corrugated carton production and storage process, this study contributes present investigations by examining the productivity improvement by applying $5 \mathrm{~S}$, work study, and Muda elimination principles to diminish the work process and rectify the working method, while setting up a new working area according to the principle of $5 \mathrm{~S}$ to allow employees in the warehouse to work more easily. In addition, this study struggles to decrease quality problems, wastes, delays and the number of defects that affect the cost of the company by waste elimination principles which enable the company to be more competitive in the industry.

\section{LITERATURE REVIEW}

\section{A. Productivity}

A comprehensive explanation of productivity is the association between the output produced by a service or production process and the input supplied to generate this output [1]. Consequently, productivity is described as the effective consume of resources, e.g. labor, material, land, information, capital, energy; in the manufacturing of diverse products and services [2]. In addition, higher productivity means accomplishing more with the same amount of resources or achieving higher outputs in terms of volume and quality with the same input [3]. Moreover, productivity is viewed in terms of efficiency and effectiveness of work [2].

Since globalization has an effect on continuous competition in all business industry, many researchers have argued that the definition of productivity as the ratio between output and input as well as the terms of efficiency and effectiveness resulting from the use of the said resources

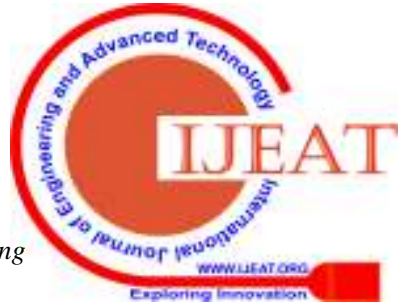


is narrow and inappropriate for measuring the success of the current business $[4,5]$. Thus, modern notion of productivity includes consideration of social and ecological costs, ability to create value for customers and stakeholders in the supply chain, ability to meet customers' requirements that change over time, survival in high competition, and agility and speed in adapting to meet customer needs $[4,5]$.

\section{B. Continuous Improvement}

Continuous improvement can be viewed as several aspects. First, continuous improvement is as much a philosophy as a set of particular techniques and quality instruments. Thus, it would be seemed to be specifically essential for executives to have an attention regarding procedure emphasizing on the appropriate method of performing things. Second, continuous improvement can be seen as generic characteristics which focus on the value of making continuous incremental changes [6]. Users emphasize on creating minor changes, amending procedures, and finally generating a substantial progressive result $[6,7]$. While each trivial alter may not have a quantifiable impact, the progressive result can be completely profound. Third, continuous improvement is viewed as improving method for both products and processes which involve employees from all positions and all departments in the company [8]. The objective is to eliminate wasteful practices [9] and achieve lean production [10]. Employees persistently chip away the fatty tissues of firm and establish lean manufacturing procedures [9]. Finally, continuous improvement is a category of meditation approach that discloses its profundity only through continual reiteration and modification [11].

The Deming's quality cycle or PDCA-cycle is used to coordinate continuous improvement efforts. The accomplishment of one cycle continues with the beginning of the next. A PDCA-cycle comprises four sequential phases or steps. First, plan step is an investigation of what requires to be made better by taking into consideration areas that possess chances for alteration, e.g. determination on what should be modified. Second, do step is an application of the alternations that are determined on in the plan phase. Third, check phase is a control and measurement of products and processes in accordance to modifications made in preceding phases and in accordance to policies, desired results and products requirements. Lastly, act step is a reaction or an adoption to the alternations or handling the PDCA-cycle through again, maintaining continuous improvement [12].

\section{C. $5 S$ Practices}

The 5S practice embarks on each programme of improvement. It is the technique for assisting the investigation of processes managing on the place of work. The 5S is the approach of generation and perpetuating effectively managed, clean, highly successful and excessive quality place of work. Its consequence is the productive company of the place of work, depletion of environment of workplace, removal of inferior results related to lack of successes and breaks, and development of workplace both safety and quality [13]. The notion of the $5 \mathrm{~S}$ has its origin in Japan, developed by Osada [14] in the early 1980s [15]. The name $5 \mathrm{~S}$ is the abbreviation of five Japanese words including Seri, Seiton, Seiso, Seiketsu, and Shitsuke.

First, Seri (sort) is aimed to sort, organize the workplace, and get rid of superfluous materials. Through the appropriate classifying, it can identify the materials, equipment, tools and inevitable information for comprehension the tasks. Sorting or classifying removes the excess of both raw materials and materials, defective products, and damaged tools and equipment. It assists to keep the polished and tidy workplace and raises the effectiveness of exploring and acquiring things, cutting the period of managing the production. Second, Seiton (set in order) aims to visualize the workplace and place for everything (e.g. painting the floor assists to determine the areas of storage of each raw material, material or transport trails; sketching the appearances of equipment and tools helps it possible for the rapid positioning aside them on the constant areas; colored labels allow to determine the raw materials, materials, surplus parts or official papers etc.). It should carry out the separation of items or objects and indicate the areas of their keeping. Third, Seiso (shine) aims to clean and remove wastes or dust. Ordinary cleaning allows to determine and to get rid of origins of disordering and to perpetuate the clean workspaces. Throughout the time of cleaning, it checks the cleanness of workplace, floor and machine, conciseness of equipment, neatness of pipes, lines, origins of light, present data, clarity and comprehensibility of provided information, etc. Indispensable is the looking after of and preservation of individual neat of the employee. Next, Seiketsu (standardize) aims to be indicated area for objects or items, consistent regulations of company, preservation and maintaining cleanness. Worked out and applied guidelines in the form of instructions and procedures allow to maintain the order on the workspaces. Guidelines should be extremely communicative, explicit and uncomplicated to comprehend. In respect of this period of arrangements and getting better, it should involve all participants of the procedure on the specified workspace; it means direct employees. The group realizes the best specificity of its own activities, and method of elaboration and after that, usage provides them chance of comprehending the essence and each manner of the operation. In the purpose of convincing all the effortless access, compulsory guidelines should be found in unchanging and perceptible areas. Finally, Shitsuke (sustain) aims to be automatic realization of the above-mentioned rules [16].

Applying the notion of the $5 \mathrm{~S}$ will desire from employees the massive self-discipline related to applying and complying with the rules of regularity in classifying and cleaning. It brings about expanding the awareness of employees, and declining the quantity of defective products and systems, advances in the internal transmission, and through this to enhancement in the human relations.

\section{Work Study}

Work study is an essential management technique to accomplish superior productivity. It is associated with 
individual work, process of performing tasks and standard of performance. The existence of any company is based on utilization of the latest technology and effective production processes. To get better effectiveness of production, it requires productive mobilization of factory, tools, equipment and employees. This can be accomplished by implementing work study which studies methods and measures the performance. It separates tasks into diminutive components, learns it, and repositions it to receive the regular or higher effectiveness at diminished cost.

Work study was defined by International Labor Organization as the procedure of method study and work measurement employed to endorse the excellent conceivable utilization of employee and material resources in managing a determined activity. It is also a supervision service dependent on method study and work measurement applied in assessment of individual work resulting in examination of all the resources that affect effectiveness and economy of situation in order to bring about development. Moreover, International Labor Organization asserts that work study is aimed to decrease cost either by designing the work for extreme productivity or by developing productivity in current job through improvement in existing processes by decreasing inefficient and squandered time [17].

\section{E. Muda Elimination}

The Muda is defined as losses and wastes which refer to any activity that does not increase any worth to the purchaser or that the purchaser is not hearty to expend for. Waste emerges in whole process and in company. No matter how effective or efficient a process may be, some degree of waste is normally displayed. Ohno, often mentioned to as the father of the Toyota Production System [18], determined seven forms of waste that occur in a process including: 1) inventory refers to the number of items of work at each activity step. Inventory waste is items beyond minimal quantities and an idle resource which takes up floor space and adds to cost such as superfluous raw material, work in process, and finished products, and redundant operating suppliers. 2) Overproduction involves excessive use of manufacturing resources or output that exceeds the customer expectation or was produced early (before it is demanded). 3) Waiting time refers to the time spent waiting between activities, queues, and idle time, which requires space and adds no value. 4) Unnecessary transporting refers to movement between activities which increases handling and work in process such as moving materials between plants or between work centers and handling more than once. 5) Overprocessing refers to unnecessary production steps and scraps such as work performed higher than customer required which requires higher resources than actual need. 6) Inefficient work methods reduce productivity and increase work in process inventory such as excess movement of equipment or employee that increases no value. 7) defective products require rework costs, returns, warranty claims, scraps, and possible lost sales due to customer dissatisfaction [12]. The indication that specifies the possibility of improvement is the existence of these wastes. The list of wastes can also indicate possible goals for continuous improvement endeavors.

\section{RESEARCH METHODOLOGY}

The purpose of this examination is to enhance productivity in corrugated carton industry. The study was conducted from November 2018 to March 2019 from XYZ Co., Ltd. The data were collected from the managers and supervisors and the problems were analyzed by brainstorming and cause and effect diagram. The current productivity is measured by the ratio between current output divided by current input. After measuring current productivity, the analyzed and improved processes were developed by means of 5S, work study, and Muda elimination. Next, the productivity after improvement was measured by the ratio between output after improvement, divided by input after improvement. Meanwhile, productivity growth was calculated by the ratio between the difference of productivity after improvement and current productivity, divided by current productivity.

Table 1. Analyzing Wastes and Problems

\begin{tabular}{|c|c|c|}
\hline $\begin{array}{l}\text { Wastes/ } \\
\text { Problems }\end{array}$ & Details & Targeted \\
\hline Machine idle time & $\begin{array}{l}\text { Employees stopped } \\
\text { machine 1-2 hours to } \\
\text { prepare materials and } \\
\text { equipment while } \\
\text { changing new } \\
\text { purchasing order }\end{array}$ & $\begin{array}{l}\text { Reduce the machine } \\
\text { idle time from } 1-2 \\
\text { hours to } 15-30 \\
\text { minutes. } \\
\text { Increase output more } \\
\text { than } 10 \text { percent }\end{array}$ \\
\hline $\begin{array}{l}\text { Defect work } \\
\text { pieces }\end{array}$ & $\begin{array}{l}\text { Material of preceding } \\
\text { order remained in the } \\
\text { machine while } \\
\text { operating machine for } \\
\text { new purchasing order }\end{array}$ & $\begin{array}{l}\text { Reduce defect work } \\
\text { pieces from } 160 \text { pieces } \\
\text { per month to less than } \\
145 \text { pieces per month }\end{array}$ \\
\hline $\begin{array}{l}\text { Take long time to } \\
\text { find quality roll of } \\
\text { corrugated paper } \\
\text { Higher defects } \\
\text { due to low quality } \\
\text { of raw materials }\end{array}$ & $\begin{array}{l}\text { Mixing among wet, } \\
\text { damp, and quality roll } \\
\text { of corrugated paper } \\
\text { Wet and damp rolls } \\
\text { interlaced or } \\
\text { overlapped to other } \\
\text { rolls of corrugated } \\
\text { paper }\end{array}$ & $\begin{array}{l}\text { Improved by } 5 \mathrm{~S} \\
\text { principles, leading to } \\
\text { ease to find and reduce } \\
\text { sorting and classifying } \\
\text { time } \\
\text { Removing wet and } \\
\text { damp roll to other } \\
\text { place leading to } \\
\text { reduced defect of raw } \\
\text { materials }\end{array}$ \\
\hline $\begin{array}{l}\text { Employees } \\
\text { ignored to comply } \\
\text { rules and } \\
\text { regulations }\end{array}$ & $\begin{array}{l}6 \text { employees ignored } \\
\text { to comply with rules } \\
\text { and regulations }\end{array}$ & $\begin{array}{l}\text { Reduce number of } \\
\text { employees who } \\
\text { neglected rules and } \\
\text { regulations from } 6 \text { to } 3 \\
\text { person. }\end{array}$ \\
\hline
\end{tabular}

Current Productivity $=\frac{\text { Current Output }}{\text { Current Input }}$

Productivity after Improvement $=$ output after improvement

Input after improvent

Productivity Growth $=$ (Productivity after Improvement-Current Productivity) Current Productivity 


\section{RESULTS AND FINDINGS}

A. Results from brainstorming and cause and effect diagram

Based on the participation and observation study together with brainstorming with managers, supervisors, and relevant employees, as shown in the figure 1, and referring to the results, it was found that crucial problems of corrugated carton production occurred from human errors which include production employees who ignored to check the availability of machines before operating the machine, and production employees who ignored to prepare material for next order while machines operating, and warehouse employees who randomly checked the humidity of warehouse area before storage corrugated sheet papers.

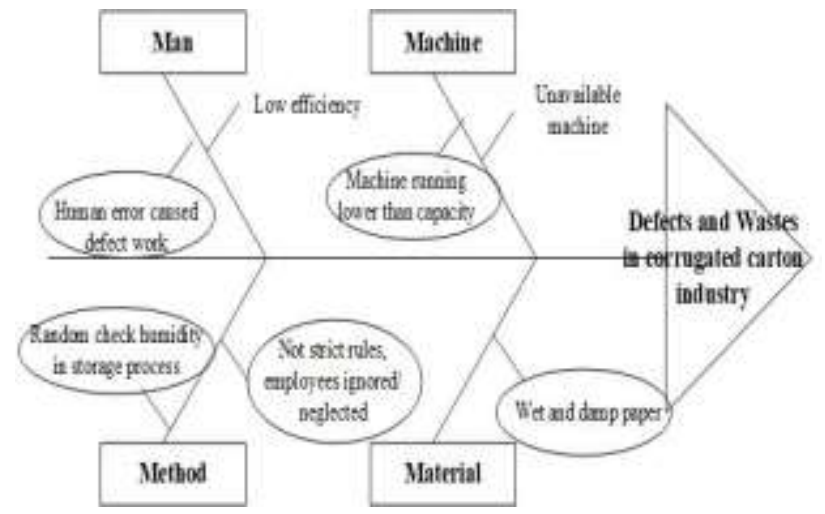

Fig.1. Results from Brainstorming and Cause and Effect Diagram

\section{B. Results of improvement in production process}

Based on work study, the results presented that there are many defect work pieces in cutting process. Considering the production process, employees could be trained about production process, machine operation, quality inspection, and planning process. The production process could be changed from operating machine without checking machine availability and removing materials remains in the machine to check availability and removing materials remains in the machine before operating new purchasing order. In addition, defect work pieces occur when changing mold for cutting process. Thus, new employees need to be well trained before starting to work. Moreover, employees disregarded to check product schedule and neglected to prepare material, cutting mold, and tools while the machine was operating which results in wastes in production department as well as stop of machines. Work instruction must include preparing materials and setting up tools and equipment while machine is operating in order to avoid and reduce machine idle time while changing to produce new model. In addition, all employees must comply with company rules seriously. After improvement, the corrugated carton output was then increased from 2,000 tons per month to 2,300 tons per month, accounting for 15.00 percent of improvement. The production defect was reduced from 160 pieces per month to 140 pieces per month, accounting for 12.50 percent of improvement.

\section{Results of improvement in warehouse area}

After work study, the results presented that rolls of corrugated paper were located in wrong position, messy, and mixing among wet, damp, and quality rolls of corrugated paper resulted in moisture penetrated to quality roll of paper, causing defect raw materials. Figure 2 shows the warehouse area before improvement while figure 3 presents warehouse after improvement.

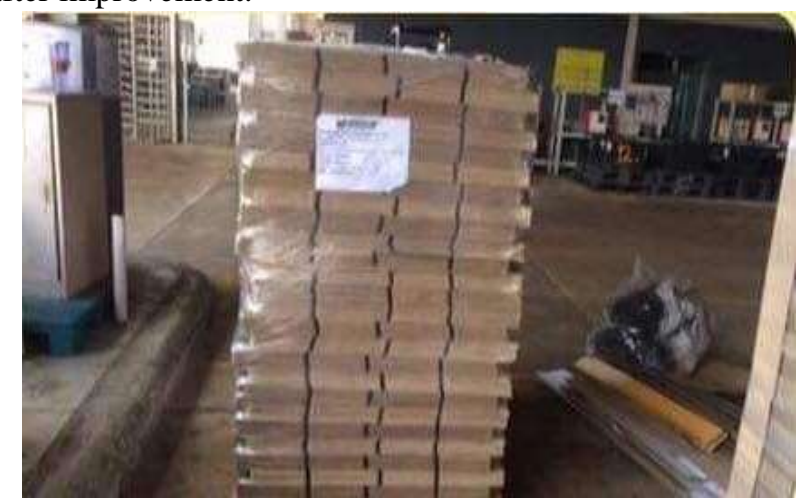

Fig.2. Warehouse Area Before Improvement

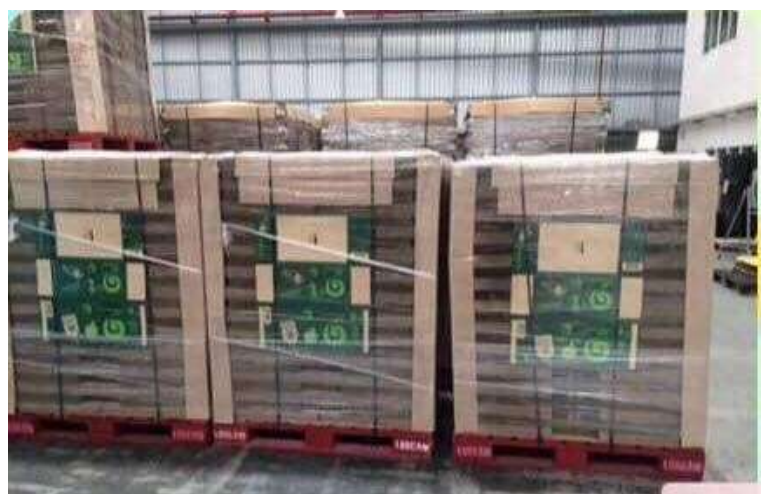

Fig.3. Improvement Warehouse Using 5S

Results of improvement in warehouse area using $5 \mathrm{~S}$ practice are as followed. First, Seri (sort) was implemented by sorting quality, defect, wet and damp rolls of corrugated paper. Then, defect, wet, and damp rolls of corrugated paper were moved or eliminated from the warehouse area. Second, Seiton (set in order) was implemented by keeping each type roll of corrugated paper according to the frequent and important usage. Written and hanged labels were provided to reduce errors and ease to utilize. Third, Seiso (shine) was implemented by regular maintaining cleanliness both working area and machine, leading to no crumbs that cause problems in the speed and safety of the machine as well as well sceneries in the workplace. Next, Seiketsu (standardize) was implemented by setting correct work instruction, training for correct work method, and seriously complying rules and regulations. Finally, Shitsuke (sustain) was implemented by maintaining the above improved systems, communicating and announcing to all employees that $5 \mathrm{~S}$ is essential and requires collaboration from employees and the compact self-discipline related to applying and complying with the regulations of generality in sorting and cleaning. In addition, the company launches $5 \mathrm{~S}$ activities at least twice a month, which all employees comply to participate. 
Regarding the storage process, once it was improved by sorting, cleaning, classifying materials, products and areas with sign boards, the results showed that the materials and products were easier to find and product quality was increased. The findings presented that the number of employees who neglected to comply with the regulations of the company was reduced from 6 persons to 2 persons, accounting for 66.67 percent of improvement.

\section{DISCUSSIONS AND CONCLUSION}

The purpose of this study is to reduce waste and improve productivity in corrugated carton industry. Brain storming and cause and effect were used to identify root causes of wastes, bottleneck, and quality problems. Referring to the results, it was found that crucial problems of corrugated carton production occurred from human error. Human error can occur from the two causes, i.e. not knowing the rules/procedures of work, and knowing but deciding to ignore them. New employees may be doing wrong due to not knowing the rules/procedures of work or misunderstanding them, and the error can be eliminated by providing well training before working and coaching while doing their job. On the other hand, current employees may be ignoring rules and regulations due to weak enforcement, considered not important. Communication is essential to solve misunderstanding problem, both top-down and bottom-up communication. Management needs to place importance on communication and benefits of obeying work instruction, rules and regulations, while focusing on $5 \mathrm{~S}$ activities and the advantages to be derived, e.g. higher productivity and income, fewer losses, wastes and working accidents. Meanwhile, employees need to transmit obstacles of complying which require to be supported from management.

Continuous improvement is known as Kaizen in Japanese. The implementation of the Kaizen notions assumes a ceaseless communication both vertical communication between the executives and the workers and horizontal communication between the workers on the same hierarchical level. The application of the Kaizen principles relates to no crucial cost, but only increased observation to details and empirical methods to do things superior and extremely effectively. The directly productive employees are particularly encouraged so that they can suggest and make improvements [19]. With a detailed analysis, the results have remarked that, even in the spaces where no improvements are required such as warehouse area, there is still a lot of probability to get better. A well management of human resources in the company is one of the strategic purposes of the firm which should be obviously described and admitted by all members. The continuous improvement concepts are the resistance structure that should be built on, so that we can obtain to a sustained and step by step improvement of the organizational performance. Difficult situations should not be linked to employees because laying the blame on employees does not find the answer to the problem. Problem solving should use feed-back techniques.

The results demonstrated that the implementation of $5 \mathrm{~S}$, work study, and Muda elimination techniques can be applied in small scale industry. These techniques involve with Toyota Production System which emphasizes on the active participation of all employee categories, aiming to small but continuous development. Muda elimination is one of the options to reduce non value-added activity (wastes) and improve operational efficiency of the organization. The efficient implementation of $5 \mathrm{~S}$ technique leads to improvement in environmental performance and thus primarily related to reduction of wastes in manufacturing. It promotes neatness in storage of raw materials and finished products, reduction in accident, and increase of awareness and moral of employees [19]. Regarding work study, both method and time study are necessary to be analyzed at the same time as changing method leads to reducing time. Regarding method improvement, it is unnecessary to change or invent new machine or equipment as method can be improved by study motion and process, eliminated unnecessary motion and movements, and rearranged or excised superfluous processes.

The findings demonstrated that $5 \mathrm{~S}$, work study, and Muda elimination can be viewed as an efficient method that can reduce waste and improve business performance which can be implemented in any industry as well as any size of company. It can be considered as the promotion of the improvement techniques amongst the employees and as a training approach for the employees. The findings demonstrated, nevertheless, that there are hurdles in the successful utilization of the improvement techniques for any improvement goal. The most crucial obstacles recognized are connected to depletion of communication, gap between the executive and shop floor operators and also the insufficiency of training and awareness of this activity amongst the employees. Therefore, the full advantages of the improvement techniques cannot be knowledgeable in the business sector as long as all the drawbacks related with application of the improvement techniques are recognized, completely comprehended and tackled. Ceaseless evaluation in all levels of firms is one major driver to change the improvement culture of the company. This evaluation should be emphasized on the progress and improvement of quantity and quality of products, level of morale and satisfaction of employee, level of quantity and quality of communication, financial performance, and customer satisfaction.

\section{RECOMMENDATIONS}

There are several recommendations as followed:

1) Japanese management and Toyota Production System techniques require a top-down technique that comes to be part of the corporate fabric. Teaching Toyota Production System techniques cannot take place in a classroom or through seminars, but where the productions actually take place. To be successful, all employees must be completely conscious of the diverse forms that waste can take and be persistently watchful of any chances to attack and get rid of these wastes. Senior managers must normally walk through the productions, keeping an eye on the activities, asking

inquiries, and expressing their dedication to the process. Too 
often, firms treat these processes as programs that can be began and ended as required. They rarely provide it the inevitable reinforce and time to turn to be a part of the organizational culture.

2) Though principle of Japanese management and Toyota Production System techniques are related to no crucial cost, only supplementary awareness to details and empirical ways is required to do things superior and extreme effectively together with continuous improvement over time. Thus, it can be applied in both manufacturing and service business. Due to the lower resource investment, it can be implemented in any company like small, medium, and large companies.

3) There are several Japanese managements and Toyota Production System techniques. This study applied some of them, i.e. 5S, work study, and Muda elimination, and the results are satisfied. It is necessary for all businesses to analyze and select suitable tools for their situations which may be similar or dissimilar to this study, for instance just in time, lean production, six sigma, push-pull system, Jidoka, Poka Yoke, Kamban, single-minute exchange of die, Hejunka, Genchi Genbutsu, visualization, respecting employees, team and suggestion system.

4) Though Japanese management and Toyota Production System techniques are pervasive implementation in worldwide business, European and Western management and techniques are applied widespread as well. Since European and Western management are involved with high technologies, machines, and innovations, which require high level of investment, a business needs to calculate break event point and payback period before deciding to invest in training course for novel equipment utilization.

\section{ACKNOWLEDGMENT}

The author would like to demonstrate gratitude to all participants who gave priceless information, including the XYZ Co., Ltd., for the consents that authorized the author to successfully perform this study.

\section{REFERENCES}

1. Prokopenko, J. Productivity Management: A Practical Hand Book. Geneva: International Labour Office; 1987.

2. Drucker PF. Management Challenges for the 21st Century. New York: Harper Collins; 1999.

3. Ruch WA. Measuring and managing individual productivity. In: Douglas HH. (eds.) Organizational linkages: understanding the productivity paradox. Washinton, D.C.: National Academy Press; 1994. p. 105 130 .

4. Lammon D. An Examination of Productivity in the Utility Industry. New York: Empire State College, State University of New York; 2010.

5. Riza AR. Methodology Development for Calculating Productivity and Its Losses to Determine Optimization Regime in Assembly Line. Malaysia: School of Manufacturing Engineering, University of Malaysia Perlis; 2011.

6. Imai M. Kaizen: The Key to Japan's Competitive Success. New York: Random House; 1986.

7. Dertouzos ML, Lester RK, Solow RM. Made in America: Regaining the Productive Edge. Cambridge, MA: MIT Press; 1989.

8. Poe R. The new discipline: unleash group intelligence in your company. Success. 1991; July/August: 80.
9. Robinson A. Continuous Improvement in Operation: A Systematic Approach to Waste Reduction. Cambridge, MA: Productivity Press; 1991.

10. Womack JP, Jones DT, Roos D. The Machine that Changed the World. New York: Rawson Associates; 1990.

11. Suzaki, K. The New Manufacturing Challenge: Techniques for Continuous Improvement. New York: The Free Press; 1987.

12. Heizer J, Render B. Operations management. 11th ed London: Pearson Education Limited; 2014.

13. Karkoszka T, Szewieczek D. Risk of the processes in the aspect of quality, natural environment and occupational safety. Journal of Achievements in Materials and Manufacturing Engineering. 2007; 20: 539-542.

14. Osada T. 5S's: Five Keys to a Total Quality Control Environment. Tokyo: Asia Productivity Organization; 1991.

15. Khamis N, Ab Rahman MN, Jamaludin KR, Ismail AR, Ghani JA, Zulkifli R. Development of $5 \mathrm{~S}$ practice checklist for manufacturing industry. Proceedings of the World Congress on Engineering 2009 Vol I, WCE 2009, July 1-3. London, U.K.

16. Sharma R, Singh, J. Impact of implementing Japanese $5 \mathrm{~S}$ practices on total productive maintenance. International Journal of Current Engineering and Technology. 2015; 5(2): 818-825.

17. International Labour Organisation. Introduction to Work Study. India: Universal Publishing Corporation; 1986.

18. Ohno T. (1988). Toyota Production System: Beyond Large-Scale Production. English translation ed. Portland, Oregon: Productivity Press; 1988.

19. Titu MA, Oprean C, Grecu, D. Applying the Kaizen method and the $5 \mathrm{~S}$ technique in the activity of post-sale services in the knowledge-based organization. Proceedings of the International Multi Conference of Engineers and Computer Scientists, 2010, Vol III, IMECS 2010, March 17-19. Hong Kong.

\section{AUTHORS PROFILE}

Dr. B. Piyachat received her bachelor's degree of production engineering from King Mongkut's University of Technology Thonburi, master degree of business administration from Mahanakorn University of Technology, and Ph.D degree in Management from Rajamangala University of Technology Thanyaburi, Thailand. She is currently working as Assistant Professor in the Faculty of Business Administration, Rajamangala University of Technology Thanyaburi (RMUTT), Thailand. She has 10 years of working experience in manufacturing industry and 5 years of teaching experience in industrial management field. 